\title{
Capital Adequacy In The Albanian Banking System; An Econometrical Analysis With A Focus On Credit Risk
}

\author{
Mr. Kledian Kodra, FCCA, PhD candidate \\ Prof. Dr. Drini Salko, Head of Department of Finance and \\ Accounting \\ Faculty of Economics and Agribusiness, \\ Agricultural University of Tirana, Albania
}

doi: 10.19044/esj.2016.v12n1p271 URL:http://dx.doi.org/10.19044/esj.2016.v12n1p271

\begin{abstract}
This paper examines the relationship between regulatory capital and credit risk within the Albanian banking sector. We estimate an equation which tries to capture the relationship among regulatory capital, nonperforming loans, profitability, total assets, liquidity and the level of growth in the GDP. The data is grouped and the analysis is performed in accordance with three banking groups. The grouping of the banks is in accordance with their size in the system and reflects the grouping used by the central bank for regulatory purposes. The model developed can be used to forecast required levels of CAR and it suggests that in the Albanian banking system, as well as for each bank group separately, the relationship between CAR and NPL is negative, the relationship between CAR and assets is negative for an unchanged level of regulatory capital, the relationship between CAR and profitability is positive, whereas the relationship between CAR and liquidity is negative. The effects of the change in the level of NPL on CAR are of a longer term nature, whereas the effect of the change in the level of assets on CAR is more of a shorter term nature.
\end{abstract}

Keywords: CAR - Capital Adequacy Ratio, RWA - Risk weighted assets, NPL - non-performing loans, LR - Liquidity ratio

\section{Introduction - Objective and Purpose}

The purpose of this study is to explore, in relative and absolute terms, the demand for additional regulatory capital in the Albanian banking system at different levels of non-performing loans. We try to study the requirement for additional regulatory capital for the three large banking groups inside the 
banking system as defined by Bank of Albania according to bank size and systemic risk.

The question we try to answer in this study is: how do various levels of non-performing loans translate into demand for additional regulatory capital in the case of the group made up of the four largest banks (G3), (with assets value greater than $7 \%$ of the total assets in the banking system), in the case of the second group made up of smaller banks (G2), (with assets value is greater than $2 \%$, but less than $7 \%$ of the total assets in the banking system), and the third group made up of smallest banks (G1), (with assets value smaller than $2 \%$ of the total assets in the sector), when the level of non-performing loans exceeds $20 \%, 25 \%$ and then $30 \%$ of the total gross loan in the system.

The requirement for additional capital is measured through the capital adequacy ratio (CAR) which is defined by the ratio of regulatory capital to the total risk weighted assets for each of the banking groups, with risk rates applied according to the bank regulations in force in Albania.

Considering CAR as the dependent variable, we will try to identity a number of independent variables and to study the nature of the relationship between the dependent and independent variables.

The dependent variables in this study are:

- non-performing loans,

- $\quad$ provision level,

- $\quad$ profitability measured as the return on assets,

- liquidity ratio, and

- $\quad$ the real rate of growth of GDP (Gross Domestic Product) in Albania.

\section{An Overview of the Banking System in Albania and the Expectations on the Behavior of the Variables used in the Study}

The banking system in Albania is made up of 16 privately-held commercial banks and accounts for $90.2 \%$ of the total assets of the overall financial sector and $92.7 \%$ of the country’s GDP, according to the financial stability report published by the Bank of Albania, as at the end of June 2015. As that date, total assets of commercial banks in Albania reached ALL 1,370 billion (EUR 10 billion) and an NPL ratio of 21\% of gross loans. The banks in Albania are divided according to size of their activity in:

Group 1 Banks each owning between $0-2 \%$ of the total assets in the banking system. Group 1 Banks currently include: United Bank of Albania (UBA), Veneto Bank (VB), International Commercial Bank (ICB), First Investment Bank (FIB), Credit Bank of Albania (CBA), Credit Agricole Bank (CAB). These banks own approximately $6.3 \%$ of the total assets of the banking sector in Albania as at 30 June 2015. 
Group 2 Banks each owning between 2-7\% of the total assets in the banking system. Group 2 banks currently include: Procredit Bank (PB), National Bank of Greece (NBG), Societe Generale Bank - Albania (SGBA), Alfa Bank - Albania (ABA), Union Bank (UB), and Tirana Bank (TB). These banks own approximately $26.2 \%$ of the total assets of the banking sector in Albania.

* Group 3 Banks each owning over 7\% of the total assets in the banking system. Group 3 banks currently include: National Commercial Bank (NCB), Raiffeisen Bank (RB), Credins Bank (CB), Intesa Sanpaolo Bank - Albania (ISBA). These banks own approximately 68.3\% of the total assets in the banking sector in Albania.

As of the end of June 2015, only two banks in the Albanian banking system are owned by Albanian capital while the other 14 banks are owned by foreign capital. One of the banks in the system has one branch in Kosovo.

During the six months period ending in June $30^{\text {th }}$, 2015, according to the same financial stability report, the assets of the Albanian banking system grew at the rate of 1.5\%, reaching 1,313 billion Lek (USD10 billion) representing $92.7 \%$ of the GDP. The faster growth of risk-weighted assets had an effect on the decrease of the capital adequacy ratio. In June 2015, the capital adequacy ratio fell to $16 \%$ from the rate of $16.8 \%$ in 2014 and $17.5 \%$ in 2013.

Group 3 banks and those banks whose origin is French and/or Albanian have a lower capitalization rate compared to banks in other groups. A summary of the indicators of capital adequacy in the banking system for each bank group according to capital and the origin of capital is shown in the table below.

Table: Capital Adequacy Rate, in percent

\begin{tabular}{|c|c|c|c|c|c|c|c|c|}
\hline Period & Sector & Gr 1 & Gr 2 & Gr 3 & Italian & French & Greek & Albanian \\
\hline June 2015 & 15.9 & 19.8 & 17.5 & 15.1 & 16.6 & 13.5 & 19.4 & 14.3 \\
\hline $\begin{array}{c}\text { December } \\
\text { 2014 }\end{array}$ & 16.8 & 22.5 & 15.1 & 17.0 & 17.4 & 14.5 & 17.2 & 14.4 \\
\hline June 2014 & 17.5 & 23.7 & 14.4 & 18.2 & 19.7 & 14.1 & 16.3 & 14.9 \\
\hline
\end{tabular}

Source: Bank of Albania

\section{Our Expectations on the Behavior of the Variables Subject to This Study}

It is widely accepted that the relationship between regulatory capital and credit risk, expressed in the level of non-performing loans in the system, is negative (Jokipii and Milne (2010) for the USA dhe Aggarwal and Jacques (2001) dhe Lindguist (2004) for Norway). An increase in the level of nonperforming loans (NPL) would result in the need for additional provisions and therefore reduce operational profits and erode the regulatory capital base 
of the bank. The review of the literature on the topic suggests that researchers largely agree on the negative nature of the relationship, with certain exemptions. Jokipii and Milne (2010) for the USA dhe Aggarwal and Jacques (2001) dhe Lindguist (2004) for Norway prove the negative relationship. Nevertheless, there are exemptions to the above relationship as argued by Berger et al. (2008) and Shrieves \& Dahl (1992) as well as Rime (2001) in the case of Switzerland.

The provisioning level manifests e negative relationship against the regulatory capital level. An increase in the provisioning level is associated with a decrease in regulatory capital and CAR. The higher the provisioning level for a certain portfolio, the higher the additional regulatory capital required to be held by the bank.

It is also widely accepted that the relationship between the level of assets and CAR is negative. The higher the level of assets in the bank group, the lower the ratio CAR will be, for an unchanged level of regulatory capital.

On the other hand, profitability, measured by the return on assets, is assumed to have a positive relationship with CAR, since a higher level of profits, for the same asset level for each banking group, would result in a higher regulatory capital and therefore a higher CAR (Athanasoglou, et al., 2006, Berger, 1995).

Liquidity is a variable that is not taken in consideration in many studies on credit risk. In this study, we measure bank liquidity as a ratio of short-term assets to short term borrowings and liabilities. Some researchers argue that a bank with a high level of liquidity could lower capital and raise the credit risk it undertakes. What we just mentioned is felt more by the smaller banks (Allen and Gale, 2003). In this case, the relationship between liquidity and CAR would be negative since it reflects the incentive of banks with higher levels of liquidity to lower the level of regulatory capital and therefore lower CAR. There may also be cases when liquidity manifests a positive relationship with capital. (Athanasoglou, 2010).

Lastly, the level of economic activity, as measured by the GDP growth rate, is thought to reflect a negative relationship with CAR since it raises risk-weighted assets, for a given regulatory capital, and lowers the level of reported CAR. The increase in bank assets is expected to happen as a consequence of the increase in loans provided by the bank to satisfy the increased requests for loans on the part of the economic agents. Certainly, our assumption might fall in other specific cases, since credit extension depends on other factors as well. For example, a bank may have reached a point beyond which a new loan granted increases its reported profit by a smaller amount relative to the increase in the requirement for additional capital from the shareholders on the same loan. Therefore, the shareholders may decide to no longer offer new loans without first finding new 
satisfactory sources of finances. Literature in this regard abounds. Meri Papavangjeli, Department of Research, Bank of Albania in her paper "Impact of the macroeconomic factors on credit risk” and Elona Dushku (Department of Research) and Argita Frashëri (Department of Financial Stability within Bank of Albania) in her paper "Loan loss provisions and procyclicality: Evidence from banks in Albania”.

During our analysis, we will be mindful of another important indicator that is the size of the bank. This is the reason for the division of the banks in groups according to the banks' total assets. The larger the bank, the higher the level of assets and the higher the level of CAR that the bank reports (safe bank), the lower the credit risk the bank undertakes, since large banks can find alternative investments in addition to loans and they can find funds from capital markets without the need to request additional regulatory capital from its shareholders (Athanoasoglu 2010).

According to Michael B. Gordy (Board of Governors of the Federal Reserve System Washington, DC) Eva Lütkebohmert (University of Bonn), in their paper "Granularity adjustment for Basel II" several risk factors impact the return on assets either promptly or with a time lag. For this reason, we have built econometric model incorporating the time lag effect. Such models were not made part of the current article.

\section{The Econometric Model}

The empirical work based on the regression analysis studies the the relationship between the regulatory capital, non-performing loans, profitability, level of assets, liquidity, and gross domestic product. The data used in the development of the econometric model is obtained from Bank of Albania and were available for each of the variables mentioned above for quarterly periods starting from the first quarter of 2005 until the first quarter of 2015. The data are divided according to the three groups in the Albanian banking system.

\section{Group Data Analysis}

Descriptive Statistics for Each Bank Group

Summary Statistics for profitability

\begin{tabular}{|c|c|c|c|c|c|c|c|c|}
\hline Group & Count & Average & $\begin{array}{c}\text { Standard } \\
\text { deviation }\end{array}$ & $\begin{array}{c}\text { Coeff. of } \\
\text { variation }\end{array}$ & Minimum & Maximum & Range & $\begin{array}{c}\text { Stnd. } \\
\text { skewness }\end{array}$ \\
\hline 1 & 36 & 0.236667 & 0.121208 & $51.2147 \%$ & 0.04 & 0.61 & 0.57 & 2.97801 \\
\hline 2 & 36 & 0.101389 & 0.113141 & $111.591 \%$ & -0.05 & 0.41 & 0.46 & 2.46073 \\
\hline 3 & 36 & 0.00666667 & 0.0666762 & $1000.14 \%$ & -0.13 & 0.14 & 0.27 & 0.143326 \\
\hline Total & 108 & 0.114907 & 0.139421 & $121.334 \%$ & -0.13 & 0.61 & 0.74 & 3.8549 \\
\hline
\end{tabular}




\begin{tabular}{|c|c|}
\hline Group & Stnd. Kurtosis \\
\hline 1 & 2.16425 \\
\hline 2 & 0.538528 \\
\hline 3 & -0.0805573 \\
\hline Total & 1.99633 \\
\hline
\end{tabular}

This table shows various statistics for profitability for each of the 3 bank groups. The one-way analysis of variance is primarily intended to compare the means of the different levels, listed here under the Average column.

\section{Profitability Variance Analysis According to Group}

ANOVA Table for profitability by Group

\begin{tabular}{|c|c|c|c|c|c|}
\hline Source & Sum of Squares & Df & Mean Square & F-Ratio & P-Value \\
\hline Between groups & 0.962069 & 2 & 0.481034 & 45.18 & 0.0000 \\
\hline Within groups & 1.11783 & 105 & 0.010646 & & \\
\hline Total (Corr.) & 2.0799 & 107 & & & \\
\hline
\end{tabular}

P-value of the F-test is less than 0.05 , so there is a statistically significant difference between the mean profitability from one level of Group to another at the $95.0 \%$ confidence level.

This is illustrated also in the graph below depicting the segments representing each group means confidence interval at the level of 95\%

Means and 95.0 Percent LSD Intervals

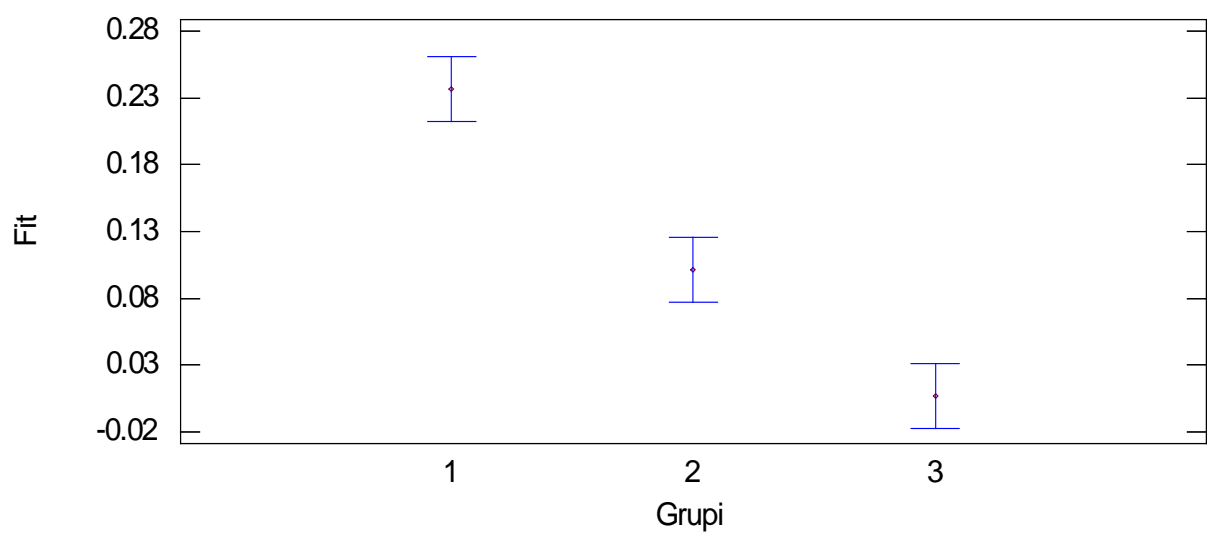

The same is illustrated with the Multiple Range Test comparing averages in couples as depicted below. Each bank group is in itself a homogeneous group significantly differring from each of the remaining groups. 
Multiple Range Tests for Fit by Grupi

Method: 95.0 percent LSD

\begin{tabular}{|c|c|c|c|}
\hline Group & Count & Mean & Homogeneous Groups \\
\hline 3 & 36 & 0.00666667 & $\mathrm{X}$ \\
\hline 2 & 36 & 0.101389 & $\mathrm{X}$ \\
\hline 1 & 36 & 0.236667 & \\
\hline
\end{tabular}

\begin{tabular}{|c|c|c|c|}
\hline Contrast & Sig. & Difference & + - Limits \\
\hline $1-2$ & $*$ & 0.135278 & 0.0482214 \\
\hline $1-3$ & $*$ & 0.23 & 0.0482214 \\
\hline $2-3$ & $*$ & 0.0947222 & 0.0482214 \\
\hline \multicolumn{4}{|c}{} \\
\hline
\end{tabular}

In the table above we can read the difference in profitability between groups.

\section{ANOVA for CAR}

The following table table shows various statistics for CAR for each of the 3 levels of groups (Group).

Summary Statistics for CAR

\begin{tabular}{|c|c|c|c|c|c|c|c|c|}
\hline Group & Count & Average & $\begin{array}{c}\text { Standard } \\
\text { deviation }\end{array}$ & $\begin{array}{c}\text { Coeff. of } \\
\text { variation }\end{array}$ & Minimum & Maximum & Range & $\begin{array}{c}\text { Stnd. } \\
\text { skewness }\end{array}$ \\
\hline 1 & 42 & 0.186981 & 0.045498 & $24.333 \%$ & 0.0711 & 0.29576 & 0.22466 & 0.796518 \\
\hline 2 & 40 & 0.0885547 & 0.0131367 & $14.8345 \%$ & 0.05065 & 0.10641 & 0.05576 & -2.96968 \\
\hline 3 & 41 & 0.0697902 & 0.0194448 & $27.8618 \%$ & 0.03192 & 0.09414 & 0.06222 & -2.05975 \\
\hline Total & 123 & 0.115909 & 0.0597819 & $51.5767 \%$ & 0.03192 & 0.29576 & 0.26384 & 4.67556 \\
\hline
\end{tabular}

\begin{tabular}{|c|c|}
\hline Grupi & $\begin{array}{c}\text { Stnd. } \\
\text { kurtosis }\end{array}$ \\
\hline 1 & 0.416289 \\
\hline 2 & 1.57336 \\
\hline 3 & -1.0614 \\
\hline Total & 0.661927 \\
\hline
\end{tabular}

The next table is to show whether there are significant differences between groups for CAR.

ANOVA Table for CAR by Grupi

\begin{tabular}{|c|c|c|c|c|c|}
\hline Source & Sum of Squares & Df & Mean Square & F-Ratio & P-Value \\
\hline Between groups & 0.329286 & 2 & 0.164643 & 185.12 & 0.0000 \\
\hline Within groups & 0.106727 & 120 & 0.000889393 & & \\
\hline Total (Corr.) & 0.436013 & 122 & & & \\
\hline
\end{tabular}

Since the P-value of the F-test is less than 0.05, there is a statistically significant difference between the mean CAR from one level of Group to another at the $95.0 \%$ confidence level. 


\section{Multiple Range Tests for CAR by Group}

The following analysis shows that there are significant differences of group means for CAR.

\begin{tabular}{|c|c|c|c|}
\hline Contrast & Sig. & Difference & +/- Limits \\
\hline $1-2$ & $*$ & 0.0984262 & 0.0130452 \\
\hline $1-3$ & $*$ & 0.117191 & 0.0129634 \\
\hline $2-3$ & $*$ & 0.0187645 & 0.0131225 \\
\hline \multicolumn{4}{|c}{$*$ denotes a statistically significant difference. }
\end{tabular}

An asterisk has been placed next to 3 pairs, indicating that these pairs show statistically significant differences at the $95.0 \%$ confidence level. The method currently being used to discriminate among the means is Fisher's least significant difference (LSD) procedure.

\section{Econometric Modeling for CAR}

Our attempt to develop an econometric model for CAR dependent on variables, such as: non-performing loans (NPL), liquidity ratio (LR), assets, profitability (fit), and rate of growth in GDP was focused on both one factor models and econometric models of multiple factors. In the regression models with one variable, we attempt to express the relationship between CAR and total assets, CAR and profitability, CAR and liquidity, CAR and NPL, profitability and assets, and the relationship between CAR and the belonging-in-a-certain-banking-group G1, G2, or G3. Keeping in mind that regression models of multiple factors are closer to reality, we decided to elaborate only on them as follows.

\section{Possible multi factor econometric models:}

a) Dependent variable: CAR

Independent variables:

D2 (Group 2)

D3 (Group 3)

Assets

Fit (Profitability)

Lratio

\begin{tabular}{|c|c|c|c|c|}
\hline & & Standard & T & \\
\hline Parameter & Estimate & Error & Statistic & P-Value \\
\hline CONSTANT & 0.176397 & 0.00766889 & 23.0016 & 0.0000 \\
\hline D2 & -0.117928 & 0.00836389 & -14.0997 & 0.0000 \\
\hline D3 & -0.173407 & 0.0149761 & -11.5789 & 0.0000 \\
\hline Assets & $1.20837 \mathrm{E}-7$ & $2.0584 \mathrm{E}-8$ & 5.87042 & 0.0000 \\
\hline Profitability & 0.000596545 & 0.000216366 & 2.75711 & 0.0070 \\
\hline Lratio & -0.625796 & 0.18453 & -3.3913 & 0.0010 \\
\hline
\end{tabular}




\begin{tabular}{|l|l|l|l|l|l|}
\hline Source & Sum of Squares & $D f$ & Mean Square & F-Ratio & $P$-Value \\
\hline Model & 0.255315 & 5 & 0.0510629 & 101.58 & 0.0000 \\
\hline Residual & 0.0492628 & 98 & 0.000502682 & & \\
\hline Total (Corr.) & 0.304578 & 103 & & & \\
\hline
\end{tabular}

R-squared $=83.8259$ percent

The model is:

\section{CAR $=0.176397-0.117928 * D 2-0.173407 * D 3+1.20837 E-7 *$ Assets + 0.000596545*Fit - 0.625796* Lratio}

Since the P-value in the ANOVA table is less than 0.05 , there is a statistically significant relationship between CAR and the other variables at the $95.0 \%$ confidence level.The R-Squared statistic indicates that the model as fitted explains $83.8259 \%$ of the variability in CAR.

All variables are significant because for all coefficients probabilties are less then 5\% significance level.

We can observe that additional assets are associated with higher levels of CAR, whereas has Lratio a negative influence. Further on, with regard to the CAR we observe that there are significant group differences, and CAR for group 2 and group 3 are less than CAR for group 1 by 0.11 and 0,17 respectively.

More technically we can read the model as follows:

An increase in assets by one unit, other factors remaining constant, is associated with an increase in CAR by $1.20837 \mathrm{E}-7$ units; an increase in profitability (Fit) by one unit, ceteris paribus, leads to an increase in CAR by 0.000596545 units; an increase in Lratio by one unit, other factors remaining constant, leads to a decrease in CAR by -0.62 units.

b) Dependent variable: CAR

Below we present an altenative model for CAR, in terms of factors influencing it,

Independent variables:

D2

D3

NPL

Fit (Profitability)

Lratio

\begin{tabular}{|c|c|c|c|c|}
\hline & & Standard & T & \\
\hline Parameter & Estimate & Error & Statistic & P-Value \\
\hline CONSTANT & 0.176257 & 0.00750708 & 23.4788 & 0.0000 \\
\hline D2 & -0.105985 & 0.00703793 & -15.0591 & 0.0000 \\
\hline D3 & -0.12425 & 0.00833828 & -14.9012 & 0.0000 \\
\hline NPL & $6.85173 E-7$ & $1.0865 E-7$ & 6.30624 & 0.0000 \\
\hline Fit & 0.000737557 & 0.000211924 & 3.4803 & 0.0007 \\
\hline Lratio & -0.602777 & 0.176774 & -3.40988 & 0.0009 \\
\hline
\end{tabular}


Analysis of Variance

\begin{tabular}{|c|c|c|c|c|c|}
\hline Source & Sum of Squares & Df & Mean Square & F-Ratio & P-Value \\
\hline Model & 0.257212 & 5 & 0.0514425 & 106.44 & 0.0000 \\
\hline Residual & 0.0473652 & 98 & 0.000483318 & & \\
\hline Total (Corr.) & 0.304578 & 103 & & & \\
\hline
\end{tabular}

R-squared $=84.4489$ percent

The equation of the fitted model is:

CAR $=0.176257-0.105985 * \mathrm{D} 2-0.12425 * \mathrm{D} 3+6.85173 \mathrm{E}-7 * \mathrm{NPL}+$ 0.000737557*Fit - 0.602777* Lratio

Since the P-value in the ANOVA table is less than 0.05, there is a statistically significant relationship between CAR and the other variables at the $95.0 \%$ confidence level.

The R-Squared statistic indicates that the model as fitted explains $84.4489 \%$ of the variability in CAR.

We observe that NPL and Fit are associated with higher levels of CAR, whereas Lratio exibits a negative relationship. Again CAR for groups 2 and 3 are less than CAR for group 1 (by -0.10 and -0.12 respectively). More technically we can read the model as follows:

An increase in NPL by one unit, other factors remaining constant, is associated with an increase in the required CAR level by 6.85173E-7 units; Increase of Fit by one unit other factors remaining constant leads to an increase of CAR by 0.000737557 units; Increase of Lratio by one unit other factors remaining constant leads to a decrease of CAR by -0.60277 units.

Differences between coefficients for Fit and Lration in two models are due to interdependences between factor variables in the two models.

\section{Conclusion}

This econometric analysis indicates that the expectations of economists for the relationship between CAR as a dependent variable, and profitability, NPL, liquidity, risk-weighted assets, and rate of increase of the GDP are verified in Albania. In addition, this analysis indicates that the division of banks in Albania for analysis, as well as regulatory purposes, in three groups according to their assets size is appropriate since each group manifests a different behavior of the dependent variable for the same conditions and variables. The groups used by the Bank of Albania and in this study are homogeneous.

The econometric models prove, at high statistical confidence levels, that in the Albanian banking system as well as for each bank group separately, the relationship between CAR and NPL is negative, the relationship between CAR and assets is negative for an unchanged level of regulatory capital, the relationship between CAR and profitability is positive, 
whereas the relationship between CAR and liquidity, and CAR and rate of increase of GDP remains negative.

Our regression analysis above, can be used to estimate the requirement for additional regulatory capital for each banking group at various levels of the independent variables, such as NPL, profitability, liquidity, risk-weighted assets, etc.

The modelling suggested that the CAR in the Albanian banking system is affected, among other variables, by the level of assets and the level of NPL. The change in the NPL level would affect CAR mostly for the longer term whereas the change in the level of assets would result in short term effects.

Lastly, we would like to mention the latest regulatory initiative of the Bank of Albania which requires that Albanian commercial banks adopt a new rule for calculating CAR, bringing the model in use closer to the requirements set forth by Basel II. The new rules may result in lower levels of risk-weighted assets and they may require banks to keep additional regulatory capital to account for operational and market risk.

\section{References:}

Basel Committee on Bank Supervision. The New Basel Capital Accord. Second Consultative Paper, Bank for International Settlements, January 2001.

Basel Committee on Bank Supervision. Basel II: International convergence of capital measurement and capital standards: A revised framework. Publication No. 128,Bank for International Settlements, June 2006.

Bank Capital and Risk in the South Eastern European Region Athanasoglou, Panayiotis P. (May 2011).

S. Emmer and D. Tasche. Calculating credit risk capital charges with the one-factor model. Journal of Risk, 7:85-101, 2005.

Granularity adjustment for Basel II Michael B. Gordy (Board of Governors of the Federal Reserve System Washington, DC) Eva Lütkebohmert (University of Bonn)

Meri Papavangjeli, Departamenti i Kërkimeve, Banka e Shqiperise "Ndikimi i faktorëve makroekonomikë në rrezikun e kredisë”

Elona Dushku (Departamenti i Kërkimeve) dhe Argita Frashëri (Departamenti i Stabilitetit Financiar dhe Statistikës në Bankën e Shqipërisë) në punimin "Provigjionimi për humbje nga huatë dhe prociklikaliteti: Evidenca Nga Bankat në Shqipëri”

Acerbi, C. and Tasche, D. (2002) Expected Shortfall: a natural coherent alternative to Value at Risk. Economic Notes 31(2), 379-388.

T. Wilde. IRB approach explained. Risk Magazine, 14(5):87-90, 2001a. 
Frey, R. and McNeil, A. (2003) Dependent Defaults in Models of Portfolio Credit Risk. Journal of Risk 6(1), 59-92.

Michael B. Gordy (Board of Governors of the Federal Reserve System Washington, DC) Eva Lütkebohmert (University of Bonn) "Granularity adjustment for Basel II”.

Gordy, M. (2003) A Risk-Factor Model Foundation for Ratings-Based Bank Capital Rules. Journal of Financial Intermediation 12(3), 199-232.

Gouri'eroux, C., Laurent, J. P. and Scaillet, O. (2000) Sensitivity analysis of Values at Risk. Journal of Empirical Finance, 7, 225-245.

Pykhtin, M. and Dev, A. (2002) Analytical approach to credit risk modelling. RISK 15(3), S26-S32.

Tasche, D. (1999) Risk contributions and performance measurement. Working paper, Technische Universitat Munchen.

http://citeseer.nj.nec.com/tasche99risk.html

Tasche, D. and Theiler, U. (2004) Calculating Concentration-Sensitive Capital Charges with Conditional Value-at-Risk. In: "Operations Research 2003”, Ahr, D., Fahrion, R., Oswald, M. and Reinelt, G. (Eds.), 261-268. Springer, Heidelberg. Wilde, T. (2001) Probing granularity. RISK 14(8), 102-106. 